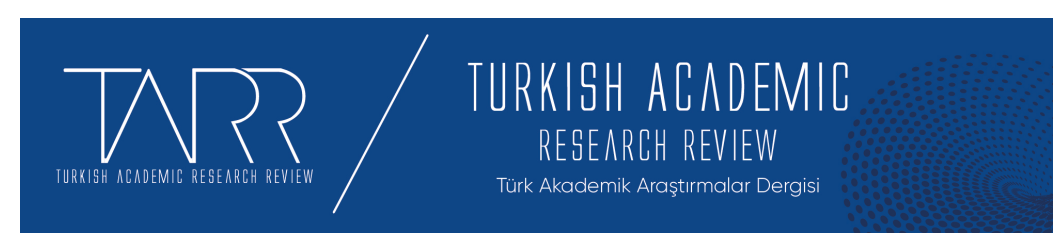

e-ISSN: 2602-2923 Yıl/Year: 2021 Cilt/Volume: 6 Sayı/Issue: 2

\title{
Türkiye'de Sosyal Medya Bağımlılığı ve Kullanımı Araştırması
}

The Analysis of Social Media Addiction and Usage in Turkey

\section{Mustafa USLU}

Doç. Dr., Akdeniz Üniversitesi Eğitim Fakültesi, Eğitim Bilimleri Bölümü, Rehberlik ve Psikolojik Danışmanlık A.B.D.

Assoc. Prof. Dr., Akdeniz University, Education Faculty, Psychological Counselling and Guidance, mustafauslu@akdeniz.edu.tr, Orcid ID: 0000-0003-3622-0892

\begin{tabular}{r|l} 
Makale Bilgisi & Article Information \\
Makale Türü - Article Type & Araştırma Makalesi / Research Article \\
Geliş Tarihi - Date Received & 5 Mayıs / May 2021 \\
Kabul Tarihi - Date Accepted & 23 Haziran / June 2021 \\
Yayın Tarihi - Date Published & 25 Haziran / June 2021 \\
Yayın Sezonu & Nisan - Mayıs- Haziran \\
Pub Date Season & April - May - June
\end{tabular}

Atıf / Cite as: Uslu, M. (2021), Türkiye'de Sosyal Medya Bağımlılığı ve Kullanımı Araştırması/The Analysis of Social Media Addiction and Usage in Turkey. Turkish Academic Research Review, 6 (2), 370-396. Retrieved from https://dergipark.org.tr/tr/pub/tarr/issue/62824/933479

Intihal / Plagiarism: Bu makale, en az iki hakem tarafından incelenmiş ve intihal içermediği teyit edilmiştir. / This article has been reviewed by at least two referees and confirmed to include no plagiarism. https://dergipark.org.tr/tr/pub/tarr

Copyright (C) Published by Mehmet ŞAHIN Since 2016- Akdeniz University, Faculty of Theology, Antalya, 07058 Turkey. All rights reserved.

Turkish Academic Research Review - Türk Akademik Araştırmalar Dergisi 


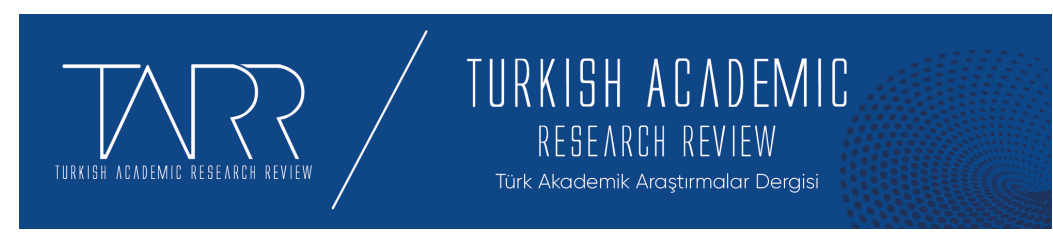

e-ISSN: 2602-2923 Yll/Year: 2021 Cilt/Volume: 6 Sayı/Issue: 2

\title{
Türkiye'de Sosyal Medya Bağımlılığı ve Kullanımı Araştırması Mustafa USLU
}

$\ddot{O} \mathbf{z}$

Amaç: Bu araştırmanın amacı Türkiye'de insanların farklı cinsiyet, yaş, meslek, eğitim grubu vb. durumlarına göre; sosyal medya bağımlılığı, kullanım oranı, en çok kullanılan sosyal medya aracı, kullanım sıklığı ve kullanım amacının ölçülmesidir.

Yöntem: $\mathrm{Bu}$ araştırma tarama modelinde betimsel bir çalışmadır. Araştırmanın verileri, internet ortamında 'Google Forms' üzerinde hazırlanan ölçekler aracılı̆̆ıyla Türkiye geneline uygulanarak elde edilmiştir. Araştırmanın çalışma evreni Türkiye ve çalışma grubu ise uzaktan erişimle 2021 yılı anketi doldurarak araştırmaya katılan 5176 internet kullanıcısıdır. Araştırmanın verileri, kişisel bilgi formu ve Tutgun-Ünal ve Deniz (2015) tarafından geliştirilen "Sosyal Medya Bağımlılı̆̆ı Ölçeği” kullanılarak internet ortamında 'Google Forms' üzerinde online cevaplanabilecek şekle getirilmiş, ardından katılımcılar için link oluşturularak online anket tekniği ile yapılarak elde edilmiştir. Çalışmanın istatistiksel analizleri SPSS 25.0 programı kullanılarak yapılmıştır.

Bulgular: Araştırmanın bulguları gösteriyor ki, insanlar genel olarak sosyal medya kullanmaktan rahatsız değiller, aksine memnunlar. Sosyal medya uygulamalarından en fazla İnstagram uygulaması kullanılmakta, sosyal medya bağımlılığı puanları yaş attıkça azalmış fakat emeklilik az da olsa bir artış göstermiştir. Yine araştırmanın bulgularına göre sosyal medya bağımlılığ puanları en yüksek öğrenci-14-18 yaşlar ve işsiz(çalışmayan) kesimde çıkmıştır. Sosyal medya bağımlılığı puanları ile sosyal medyada geçirilen süre arasında pozitif ilişki olduğu görülmüş, bekarlarda evlilere nazaran ve kadınlarda erkeklere nazaran daha yüksek olduğu görülmüştür.

Anahtar Kavramlar Sosyal medya Sosyal medya bağımlılı̆̆ı, bağımlılık, internet, iletişim, psikoloji

\section{The Analysis of Social Media Addiction and Usage in Turkey}

\begin{abstract}
Purpose: The purpose of this research is to analyse social media addiction, usage rate, the most used social media tool, usage frequency and purpose of use according to different gender, age, profession, education level, etc. of people in Turkey.
\end{abstract}

Method: This research is a descriptive study in survey model. The data were obtained by applying the scales prepared on "Google Forms" in the internet environment throughout Turkey. The population of the research is Turkey, and the sample is 5176 internet users who completed the survey in 2021 via remote access. The data were collected using the online survey technique through the Personal Information Form and the "Social Media Addiction Scale" developed by TutgunÜnal and Deniz (2015). These scales were firstly transformed into a "Google Forms" form, and then a link was created for the participants to answer online. Statistical analysis of the study was done using the IBM SPSS Statistics 25 program.

Turkish Academic Research Review - Türk Akademik Araştırmalar Dergisi 
Findings: The findings of the study showed that people are generally not uncomfortable using social media, but rather satisfied. The study also revealed that the Instagram is the most used social media application, and social media addiction scores have decreased with age, but increased slightly during retirement. In addition, according to the findings of the study, social media addiction scores were the highest among students aged 14-18 and unemployed (not working). It was finally found out that there was a positive relationship between social media addiction scores and the time spent on social media; higher in singles compared to married people and women compared to men.

Keywords: Social media, social media addiction, addiction, internet, communication, psychology

\section{Structured Abstract}

As in the whole world, with the pandemic process in our country, home closure, the participation of students in distance education from home, business life with remote internet access has made a very large segment of society connected to screens for very long hours.

The aim of this research is to identify people of different gender, age, profession, education group, etc. in Turkey. according to their situation; social media usage rate, the most used social media tool, frequency of use and measuring the purpose of use.

Method

This research is a descriptive study in survey model. The data were obtained by applying the scales prepared on "Google Forms" in the internet environment throughout Turkey. The population of the research is Turkey, and the sample is 5176 internet users who completed the survey in 2021 via remote access. The data were collected using the online survey technique through the Personal Information Form and the "Social Media Addiction Scale" developed by TutgunÜnal and Deniz (2015). These scales were firstly transformed into a "Google Forms" form, and then a link was created for the participants to answer online. Statistical analysis of the study was done using the IBM SPSS Statistics 25 program.

Findings

The findings of the study showed that people are generally not uncomfortable using social media, but rather satisfied. The study also revealed that the Instagram is the most used social media application $(\% 89,66)$, and social media addiction scores have decreased with age, but increased slightly during retirement.

-In addition, according to the findings of the study, social media addiction scores were the highest among students aged 14-18 and unemployed (not working).

- Higher in singles compared to married people and women compared to men. Based on the evaluation of social media addiction scale "74-106" score range "low addicted" because it is evaluated as "single" social media users (X: 87,08 addicted) in the category, but might be regarded as low addicted; "married" of social media users (no addiction 41-73; X:73,26), we can say that they are not addicted.

-It was seen that the first place among the participants' purposes of using social media tools was "Communicating and connecting with my loved ones" (58.64\%).

-It was seen that the first thought of the participants regarding the use of social media tools was "I don't think it has a negative effect on me" $(62.89 \%)$.

-Contrary to popular belief, most of the participants think that social media does not have a negative effect on their use of social media. Considering the number of those who say it is useful, we can say that people generally have a positive view 
of social media use. The number of people who thought that they were harmful was found very low $(12,15 \%)$.

- It was finally found out that there was a positive relationship between social media addiction scores and the time spent on social media. According to daily social media usage time, the option that respondents most marked is 1-3 hours per day (f:929; 53.8\%) spent time.

Conclusion and Discussion

The purpose of this research is to analyse social media addiction, usage rate, the most used social media tool, usage frequency and purpose of use according to different gender, age, profession, education level, etc. of people in Turkey.

This research is a descriptive study in survey model. The data were obtained by applying the scales prepared on "Google Forms" in the internet environment throughout Turkey. The population of the research is Turkey, and the sample is 5176 internet users who completed the survey in 2021 via remote access. The data were collected using the online survey technique through the Personal Information Form and the "Social Media Addiction Scale" developed by TutgunÜnal and Deniz (2015). These scales were firstly transformed into a "Google Forms" form, and then a link was created for the participants to answer online. Statistical analysis of the study was done using the IBM SPSS Statistics 25 program.

The findings of the study showed that people are generally not uncomfortable using social media, but rather satisfied. The study also revealed that the Instagram is the most used social media application, and social media addiction scores have decreased with age, but increased slightly during retirement. In addition, according to the findings of the study, social media addiction scores were the highest among students aged 14-18 and unemployed (not working). It was finally found out that there was a positive relationship between social media addiction scores and the time spent on social media; higher in singles compared to married people and women compared to men.

Nowadays, it becomes an indispensable part of the internet, and it is a fact that mobile phones and internet access and social media applications become widespread. Looking at the relevant research, research on the negative use of the internet and social media is more involved.

But data from 5,176 people, which will be considered quite a lot in our research, shows that people in general say "I am not uncomfortable with using social media" "I don't mind using social media" at $62.89 \%$, and those who say "I find it useful" at the level of $30 \%$.

Especially with the Covid 19 pandemic process all over the world, concerns about lockdowns (encompassing stay-at-home orders, curfews, quarantines, and similar societal restrictions), social distance, staying away from loved ones and the health of loved ones; distance education and screen relationship pushed people to use more internet and social media. They stated that people did not complain about this situation, on the contrary, social media contributed to them.

Social media addiction scores were highest among students aged 14-18 and unemployed (non-working) (according to the scale's assessment, they were in the less dependent category). The intensive use of social media by students has been reported in almost all studies. We have mentioned the reasons before. First, the distance education process and its dependence on the screen pushed most students to take lessons on their mobile phones. Again, it can be said that the unemployed part of the unemployed part of the students getting high SMAS scores, the excess of leisure time, the desire to search for job opportunities and to be in contact with people.

It was observed that there was a positive relationship between social media addiction scores and the time spent on social media. It is an expected result, increasing the time spent will increase the addiction. Adult guidance and assistance 
to reduce the time spent on social media to prevent addiction, especially in young people, will be important.

In the findings of the study, it was seen that the scores of social media addiction was higher in women compared to men. Especially the fact that fashion, diet, healthy eating, and shopping have an important place on Instagram will make a logical explanation for the fact that women have become more popular in this field. As is known, it can be said that women are more interested in the fields we mentioned. Again, in the data about the female brain and the male brain, it is explained to us that the parts of the brains related to communication in the womb of women are more developed from the mother's womb, their desire to communicate and connect with their loved ones, and their use of social media.

\section{Giriş}

2000'li yıllar internetin kullanımında yaygınlaşmayla beraber mobil telefon ve tablet kullanımında da yoğun artışı beraberinde getirmiştir. 2020-2021 seneleri hepimizin hayatında Covid 19 Mikrobu ve Pandemi süreciyle beraber toplumsal yasaklarla, ölümlerle ve zorluklarla hatırlanacak kuşkusuz. Pandemi döneminde insanların evlere kapalı kalmaları, sosyal mesafe kısıtlamaları, virüs hakkında bilgi ve haber edinme isteği, yalnızlık duyguları, sevdikleri ile bağ içinde olma isteği insanların sosyal medya mecralarına daha fazla yönelmesine yol açarak, zamanlarının büyük bir kısmını sosyal medya araçlarına bağlı olarak geçirmektedirler. Bu durum sosyal medya kullanım sayılarını katlamıştır.

Sosyal medya kullanımına iki yönlü bakmak gerekiyor. Alan yazını genelde olumsuz medya kullanımı araştırmaları ile dolu ve bu araştırmaların ele aldığı önemli konular "gerçekliğin" çarpıtılmasına odaklanıyor. Bunlar, kendi imajına odaklanması, kendimize ve yaşamlarımıza dair idealist bir bakış açısı sunma ihtiyacı ve beğeniler ve görüşler üzerindeki saplantıyı içerir.

Sosyal medyanın olumsuz etkilerini ele aldığımızda özellikle gençlerin büyük çoğunluğu siber zorbalığa maruz kalmakta, kişisel bilgilerinin fotoğraflarının başkaları tarafından izinsiz çalınması (hacking), ve belki de en önemlisi sosyal medya bağımlılı̆̆ın gün geçtikçe artması olarak görülebilir.

Bununla birlikte, olumlu yönlerini de ele almak gerekirse araştırmalar, salgın sırasında kullanıcıların kendileri olmaktan daha çok olmak istedikleri gibi yansıtarak daha rahat hissettiğini gösteriyor. ABD ve İngiltere'deki sosyal medya kullanıcılarının\%40'ından biraz fazlası, 2020 son aylarında sosyal medyada hayatlarının gerçekçi olmayan bir görüntüsünü gösterme konusunda daha az baskı hissettiklerini kabul ediyorlar. Belki de bunun nedeni salgının, insanların bir anlamda hepimizin aynı gemide olduğumuzu fark etmesine yardımcı olması ve bunun yerine birbirimizi desteklemeye ve birbirimizi yeniden inşa etmeye

Turkish Academic Research Review - Türk Akademik Araştırmalar Dergisi 
odaklanmış olmasıdır. Kullanıcılar, kendilerini, yaşamlarını, pandemiden etkilenim düzeylerini ve mücadelelerini paylaşırken açıkça daha rahat hissediyorlar. $\mathrm{Bu}$ süre zarfinda sosyal medyanın bunu kolaylaştırmasının olumlu etkisinin kanıtlarını görebilirsiniz.

Özellikle gençler, sosyal medyayı kullanırken; eğitim, ilişkilerini geliştirme, iş firsatları, dünyayla iletişim halinde olma ve etkilenme, e-ticaret denemeleri, iş arama ve bulma gibi çeşitli yönlerden yararlandılar (Anderson ve Jiang, 2018). Artık günümüzde Google'ın, her gencin, öğrencinin ve bilgi arayanların tüm zamanlarının öğretmeni olduğu gerçeğini kimse inkâr edemez. Google, YouTube, Wikipedia ve Khan Academy ile Facebook, İnstagram bilgi edinmek ve paylaşmak için uygun siteler haline geldi (Yang ve Lee, 2018). Nitekim Youtube videoları ile her alanda video beceri eğitimi, whatsApp grupları ile ders, iş ve aile materyal paylaşımı, tartışma, beyin firtınası vb. hayatımızın ne kadar içinde ve yarar sağladığını da göz önünde bulundurmamız gerekir (Jingjing, \& Monica, 2018). Ayrıca Sosyal medya, gençler arasında yeni bir iletişim ve ilişki yaratmaya da katkı sağlayan önemli bir rol oynamaktadır (Rachel, 2016). Yeni arkadaş edinme, çocukluk arkadaşlarını bulma, akrabalarla bağ içinde olma konusunda vazgeçilmez alan olarak kullanılmaktadır (Parents,2018).

Bağımlılık üzerine farklı tanımlamalar yapabilmek mümkündür. Türk Dil Kurumu'na göre "bağımlı"; "başka bir şeyin istemine, gücüne veya yardımına bağlı olan, özgürlüğü, özerkliği olmayan, tabi" ve "bir kimseye veya şeye maddi veya manevi yönden aşırı bağlı olan" gibi anlamlara gelmektedir. Bağımlılık ise; "bağımlı olma durumu, tabiiyet" durumunu ifade etmektedir. (TDK, 2021) Psikologlar ve psikiyatristler bir nesneye olan bağımlılı̆̆ nesneyi planladığından daha fazla kullanmak, kullanımı azaltmayı düşünmek veya kullanımı azaltmak için tekrarlayan başarısız denemeler, nesneyi kullanabilmek için önemli sosyal, ailevi ve mesleki aktiviteleri bırakmak gibi kriterleri olan bir hastalık olarak tanımlamışlardır (Kubey \& Csikszentmihalyi, 2002).

Bağımlılığın temel olarak iki kolu bulunmaktadır. Bu kollardan ilki madde bağımlılığı, diğeri ise davranışsal bağımlılıktır. Kullanıldığında bireylerin fiziksel, zihinsel, biyolojik yapısına zarar veren, değişik yollarla alınan ve beyinsel işlevlerde değişim yaratan alkol, esrar, eroin, kokain gibi reçete ile verilmeyen maddeleri sürekli olarak alma arzusu madde bağımlılığı olarak ifade edilmektedir (Çakır, Horzum \& Ayas, 2011). Davranışsal bağımlılık ise belirli bir davranışın düzenli bir şekilde sürekli sergilenmesi neticesinde bireyin psikolojik, bedensel ve toplumsal yapı dahilinde dengesini kaybetmesi, düzeninin bozulması ve çevreden giderek 
kopmasına neden olan durumdur. Davranışsal bağımlılık sonucunda birey çevresi ve toplumla düzenli bir şekilde iletişim kuramamaktadır (Büyükaslan ve Kınık 2015). Griffiths'e (1999) göre bağımlı davranış ölçütleri; Dikkat çekme, Duygudurum değişikliği, Tolerans, Yoksunluk, Çatışma ve Nüks tür. (Griffiths M, 1999).

Sosyal medya bağımlılığı, alan yazında rapor edilmiş tıpkı diğer bağımlılık türleri gibi (oyun bağımlılığı, alışveriş bağımlılığı, alkol bağımlılığı, madde bağımlılığı, internet bağımlılığı) bir psikolojik sorun olarak yerini almaktadır(Tutgun-Ünal,2015).Sosyal medya bağımlılığı; “aşırı kullanım, kullanma isteğini doyuramama, aşırı kullanımdan dolayı aktivitelerin ihmal edilmesi, aşırı kullanımın sosyal ilişkilere zarar vermesi, negatif duygu ve yaşam stresinden bir kaçış aracı olarak kullanma, kullanımı azaltma ve durdurmada problemler yaşama, kullanımın mümkün olmadığı durumlarda gergin ve sinirli olma ve kullanım süresi ve miktarına ilişkin yalan söyleme durumu" şeklinde tanımlanmaktadır (Savci M, Aysan F.,2017).

Sosyal medya kişinin;

1. Günlük iş ve eylemlerini engelliyorsa,

2. İkili ilişkilere geçişte başarısızlığa neden oluyor ise,

3. Hesaplarını kontrol etmediği her an huzursuz olup endişeleniyorsa,

4. Akademik başarısını etkiliyorsa,

5. Sanal durumları gerçeklik zannediyorsa,

6. Algı eksikliği, dikkat dağınıklığı yaratıyor ise,

7. Önceden olmayan; sonradan meydana gelen vücut fonksiyonlarında bozukluğa (panik atak, stres, öfke) sebep oluyorsa bu bir bağımlılık derecesine ulaşmış demektir (Çiftçi,2018).

İnternet ve sosyal medyanın aşırı ya da problemli kullanılması ve haftanın en az 8,5 ile 21,5 saatinin çevrimiçi geçirilmesi) bağımlılık olarak değerlendirilmektedir. (Young, 2007, Yang ve Tung, 2007)

Kesin tanı olmasa da araştırmalar ışığında; günde bir buçuk saatin üzerinde vaktinizi Facebook, İnstagram ya da Twitter gibi sosyal medyada geçirirseniz, sosyal medya bağımlısı olmuş olabilirsiniz diyebiliriz.

Turkish Academic Research Review - Türk Akademik Araştırmalar Dergisi https://dergipark.org.tr/tr/pub/tarr 
Bununla birlikte uzmanlar, sosyal medya araçlarının 'bağımlılık' derecesinde kullanımının anksiyete yani kaygı bozukluğuna neden olabileceğine dikkat çekmekte olup normal dozda kullanmayanlarda sosyal alanda iletişimle ilgili problemler, depresif bir yapı olabileceğini belirtmektedir. Bu noktadan hareketle, bazı psikologlara göre, gençler henüz iletişim becerileri gelişmiş olmadan sosyal medyayı kullandıklarında sağlıksız bir kullanım söz konusu olmakla birlikte, arkadaşlarına veya bir topluluğa da oradan mesaj vermektedir. Diğer taraftan, bu tür sanal ortamlar, büyüklerde de aynı şekilde güvensizlik yaratacağı gibi çocuklar için de benzer şekilde etki göstermektedir. Bu platformlarda kişiler, karşısındaki kişilere olduğundan daha abartılı bir şekilde yorumlar yapabilmekte veya yüz yüze söyleyemeyeceği şeyleri söyleyip yıpratabilmektedir. Bu tür durumlarda kişide yetersizlik duygusu oluşmaktadır (Baripoğlu, 2012, Kuss ve Griffiths, 2011, Aktan 2018, Akt Uslu,2020).

We Are Social ve Hootsuite 2020 yılı internet ve sosyal medya kullanım raporlarına bakıldığında dünya genelinde 4,5 milyar, Türkiye' de 60 milyon (erkeklerde \%82, kadınlarda ise \%69 ) kişinin internet kullandığını ve dünya genelinde 3,8 milyar, Türkiye' 55 milyon de kişinin aktif olarak sosyal medya kullanıcısı olduğu görülüyor. İnsanlar internette geçirdikleri toplam vaktin 3 'te 1 'ini sosyal medya platformlarında geçiriyor. Bu süre ortalama 2 saat 25 dakikaya denk geliyor. Dünya genelinde sosyal medya kullanım oranının yaklaşık \%50 olduğu verilerle ortaya konuyor. Dünya çapında ve Türkiye'de en çok kullanılan sosyal medya platformu ise Facebook. Facebook'u Whatsapp ve Youtube takip ediyor. İnstagram, Tik tok, Snapchat ve Twitter da sıralamada yer alıyor.

16-64 yaş aralığında sosyal medyada geçirilen süre bakımından Türkiye, 46 ülke içerisinde $15^{\prime}$ 'inci sırada yer alıyor. Araştırmalara göre Türkiye'deki kullanıcıların \%93'ü internette video izliyor, \%72'si müzik dinliyor, \%45'i vlog izliyor, \%43'ü radyo ve \%30'u podcast dinliyor (We are Social, Hootsuit ,2020). Bu veriler doğrultusunda, sosyal medya kullanımının giderek yaygınlaşmasının, bireylerin günlük hayatlarında hem duygusal hem de zamansal olarak büyük bir yer kaplamasının sosyal medya bağımlılığı gibi bir bağımlılık türünün ortaya çıkmasına sebep olduğu söylenebilir (Ağyar \& Uzun, 2018). DSM-5'te İnternet bağımlılığg, sosyal medya bağımlılığı ve akıllı telefon bağımlılığı bir hastalık olarak sınıflandırılmamaktadır. Yine de sosyal medyanın ağır ya da aşırı kullanımı ile ilgili davranışlar kümesi pek çok tartışmaya ve araştırmaya konu olmuştur. Bu kavramlarla ilgili çok fazla araştırmalar yapılmakta ve genel olarak davranışsal bağımlılık olarak kabul edilmektedir (Savcı ve Aysan,2017). 
Sosyal medya bağımlılı̆̆ı konusunda, bir hastalık olarak resmi bir tanı olmamasına rağmen, sosyal medyayı aşırı kullanma alışkanlığı, çok sayıda tartışma ve araştırmanın konusu olmuştur. Ülkemizde pandemi süreciyle beraber, eve kapanma, öğrencilerin evden uzaktan eğitime dahil olmaları, uzaktan internet üzeri erişimle iş yaşamı, Toplumun çok büyük kesimini çok uzun saatler ekranlara bağlı hale getirmiştir. Bu araştırmanın amacı Türkiye'de insanların farklı cinsiyet, yaş, meslek, eğitim grubu vb. durumlarına göre; sosyal medya kullanım oranı, en çok kullanılan sosyal medya aracı, kullanım sıklığı ve kullanım amacının ölçülmesidir.

\section{Yöntem}

\subsection{Araştırmanın Yöntemi Verilerin Analizi}

$\mathrm{Bu}$ araştırma insanların farklı cinsiyet, yaş, meslek, eğitim grubu vb. durumlarına göre; sosyal medya bağımlılık düzeylerini ölçmek, en çok kullanılan sosyal medya aracı, kullanım sıklık- süresi ve kullanım amacının incelendiği tarama modelinde betimsel bir çalışmadır. Tarama modelinde, geçmişte veya halen var olan bir durum birey, konu, nesne içinde bulunduğu şekilde tanımlanmaya çalışılmaktadır (Karasar, 2016)

Araştırmanın verileri, internet ortamında 'Google Docs' üzerinde hazırlanan ölçekler aracılığıyla Türkiye geneline uygulanarak elde edilmiştir. Araştırmanın verileri, kişisel bilgi formu ve Tutgun-Ünal ve Deniz (2015) tarafından geliştirilen "Sosyal Medya Bağımlılığı Ölçeği” kullanılarak internet ortamında 'Google Docs' üzerinde online cevaplanabilecek şekle getirilmiş, ardından katılımcılar için link oluşturularak online anket tekniği ile yapılarak elde edilmiştir. Çalışmanın istatistiksel analizleri SPSS 25.0 programı kullanılarak yapılmıştır. Tanımlayıcı istatistiklerin çözümlenmesinde de frekans, yüzde, aritmetik ortalama, standart sapma, minimum ve maksimum değerlerden faydalanılmıştır. Ölçekler normallik dağılımına uygun olduğundan, bağımsız 2 grubun ortalama karşılaştırılmasında bağımsız örneklem t testi, 2'den fazla bağımsız grubun karşılaştırılmasında ise One-WayANOVA (Varyans Analizi) testi, gruplar arasındaki farklılıkları Tukey HSD çoklu karşılaştırma testi kullanılmıştır.Sonuçlar \%95'lik güven aralığında, 0,05 anlamlılık düzeyinde değerlendirilmiştir. A

\subsection{Araştırmanın Çalışma Grubu}

Araştırmanın çalışma evreni Türkiye ve çalışma grubu ise uzaktan erişimle anketi doldurarak araştırmaya katılan 5176 internet kullanıcısıdır. Araştırmada elde edilen verilerin etki büyüklüğünün tahmini konusunda Cohen'in etki büyüklüğü

Turkish Academic Research Review - Türk Akademik Araştırmalar Dergisi https://dergipark.org.tr/tr/pub/tarr 
hakkında yapmış olduğu geleneksel bir sınıflandırma olan küçük, orta ve büyük seviyelere göre hesaplanmıştır. Etki büyüklüğü, kullanılan istatistiksel teste göre değişiklik gösterdiği için; "Bağımsız ortalama karşılaştırmaları .20 küçük ; .50 orta ve .80 büyük olarak belirlenmiş ve de Tek Yönlü Anova analizlerinde ise 0.01 küçük; 0.06 orta ve .14 büyük olarak hesaplanmıştır. Araştırmamızda yapılan Etki büyüklüğü hesaplama (Eta Kare) sonuçları bağımsız $t$ testi analizlerinde eta squared : 086 üzerinde ve Tek Yönlü Anova analizlerinde ise Gözlenen Güç Analizinin 1.000 olduğu bulunmuştur. Özellikle örneklem sayısının büyüklüğü, örneklemin evrene genellenebilirliği açısından yeterli görünmektedir.

Yine araştırmadan elde edilen verilerin normal dağılım gösterip göstermediği Skewness: .860 ve Kurtosis: .326 istatistiki verilere göre hesaplanmış ve $-1 / 1$ aralığı içerisinde normal dağılım gösterdiği bulunmuştur.

Araştırmaya katılan 5176 kişinin demografik özellikleri şöyledir.

\begin{tabular}{|c|c|c|c|}
\hline \multicolumn{2}{|c|}{ Tablo 1: Sosyo-Demografik Özellikler } & \multirow{2}{*}{$\begin{array}{l}\text { Katılımcı sayısı (f) } \\
2973\end{array}$} & \multirow{2}{*}{$\begin{array}{l}\% \\
57,4\end{array}$} \\
\hline & Kadın & & \\
\hline Cinsiyet & Erkek & 2203 & 42,6 \\
\hline \multirow{6}{*}{ Yaş } & $14-18$ & 816 & 15,8 \\
\hline & $19-25$ & 1247 & 24,1 \\
\hline & $26-35$ & 1472 & 28,4 \\
\hline & $36-45$ & 1079 & 20,8 \\
\hline & $46-60$ & 505 & 9,8 \\
\hline & 60 yaş Üstü & 57 & 1,1 \\
\hline \multirow{6}{*}{ Ĕ̆itim } & İlkokul & 75 & 1,4 \\
\hline & Orta okul & 100 & 1,9 \\
\hline & Lise & 1105 & 21,3 \\
\hline & Üniversite & 3228 & 62,4 \\
\hline & Yüksek lisans & 506 & 9,8 \\
\hline & Doktora & 162 & 3,1 \\
\hline \multirow{2}{*}{ Medeni Durum } & Evli & 2380 & 46,0 \\
\hline & Bekar & 2796 & 54,0 \\
\hline \multirow{3}{*}{ Meslek } & Memur & 864 & 16,7 \\
\hline & İşçi & 276 & 5,3 \\
\hline & Çiftçi & 22 & 0,4 \\
\hline
\end{tabular}




$\begin{array}{lll}\text { Esnaf } & 141 & 2,7 \\ \text { Öğretmen/ Akademisyen } & 1350 & 26,1 \\ \text { Öğrenci } & 1696 & 32,8 \\ \text { Emekli } & 85 & 1,6 \\ \text { Avukat } & 14 & 0,3 \\ \text { Özel Sektör } & 195 & 3,8 \\ \text { Serbest Meslek } & 111 & 2,1 \\ \text { Çalı̧̧mıyor } & 422 & 8,2\end{array}$

\subsection{Veri Toplama Araçları}

Kişisel Bilgi Formu. Araştırmada katılımcıların demografik özellikleri (yaş, cinsiyet, eğitim, medeni durum ve meslek), sosyal medya tercihleri (hangi sosyal medya uygulamalarını kullandıkları, en çok hangi sosyal medyayı kullandığı vb.), sosyal medya kullanım alışkanlıkları araştırmacı tarafından geliştirilen kişisel bilgi formu ile toplanmıştır

\section{Sosyal Medya Bağımlılığı Ölçeği (SMBÖ)}

Tutgun-Ünal, A. (2015) tarafından geliştirilen Sosyal Medya Bağımlılığı Ölçeği (SMBÖ) bireylerin sosyal medya bağımlılığını ölçebilmek amacıyla geliştirilmiş olup tüm geçerlilik ve güvenilirlik çalışmaları yapılmıştır. 41 maddeden ve dört faktörden (meşguliyet, duygu durum düzenleme, tekrarlama ve çatışma) oluşan SMBÖ "Her zaman", "Sık sık", "Bazen", "Nadiren" ve "Hiçbir zaman" olarak derecelendirilmiş 5'li likert türden bir ölçektir. Dört faktörlü SMBÖ’de tüm faktörler toplam varyansın \%59'unu açıklamıştır. Ölçeğin iç tutarlılık katsayısı olan cronbach alpha değeri 967 olarak belirtilmiştir. SMBÖ'den alınabilecek en yüksek puan 205, en düşük puan ise 41 'dir. Alt ölçekler ise kendi içlerinde ayrıca değerlendirilebilmektedir. Ölçekten alınan puanların değerlendirilmesinde aralıklar; 41-73 Bağımlılık Yok ; 74-106 Az Bağımlı ; 107-139 Orta Bağımlı ; 140-172 Yüksek Bağımlı ; 173-205 Çok Yüksek Bağımlı olarak belirlenmiştir.

\subsection{Veri Toplama Süreci}

İnsanların sosyal medya bağımlılığını ölçebilmek amacıyla geliştirilmiş olan Tutgun-Ünal, A. (2015) tarafindan Sosyal Medya Bağımlılı̆̆ı Ölçeği (SMBÖ), gerekli araştırma izinlerinin alınmasından sonra 2021 Ocak ayında digital hale dönüştürülüp internet ortamında 'Google Docs' üzerinde online anket haline getirilerek, araştırma evreni olan tüm Türkiye'de araştırmaya gönüllü bireylerin

Turkish Academic Research Review - Türk Akademik Araştırmalar Dergisi https://dergipark.org.tr/tr/pub/tarr 
ankete ulaşmaları sağlanmıştır. Özellikle lise ve üniversite düzeyindeki öğrencilerin katılımlarının sağlanabilmesi için uzaktan eğitim sürecinde ders anlatan öğretmenlerden yardım alınmıştır. Farklı meslek whats up grupları ve tüm sosyal mecralarda yoğun tanıtım yapılarak 20 günlük süre zarfında 5362 kişi anketi doldurmuştur. Düzgün şekilde doldurulan 5176 anket verisi araştırma bulguları için işleme alınmıştır. Yüz yüze anket çalışmalarında bu düzeyde yüksek katılımcıya ulaşabilmenin yıllar alabileceğini ve de zaman ve emek açısından çok yüksek maliyetler oluşturabileceği malumdur. Gerek verilerin elde edilmesi gerekse işlenmesi açısından uzaktan erişimin çok büyük kolaylık sağladığı görülmüştür. Literatür incelendiğinde bu sayıda kişiye ulaşılarak yapılan araştırmaların neredeyse yok denecek kadar az olduğu görülebilir.

\section{BULGULAR VE TARTIŞMA}

Bu bölümde araştırmadan elde edilen bulgulara yer verilmiştir.

Tablo 2 Sosyal Medya Kullanım Bilgileri f, \% tablosu

\begin{tabular}{|c|c|c|c|}
\hline \multirow{7}{*}{$\begin{array}{l}\text { En Çok hangi S.M. } \\
\text { Uygulamasını } \\
\text { Kullanıyorsunuz? }\end{array}$} & & f (tercih edilme & $\%$ \\
\hline & İnstagram & 4641 & 89,67 \\
\hline & Facebook & 2919 & 56,51 \\
\hline & Twitter & 2416 & 46,69 \\
\hline & Swarm & 100 & 1,94 \\
\hline & Reddit & 71 & 1,33 \\
\hline & Tinder & 52 & 0,93 \\
\hline \multirow{7}{*}{$\begin{array}{lr}\text { Sosyal } & \text { Medya } \\
\text { Kullanım } & \text { Amacinız } \\
\text { Nedir? } & \end{array}$} & $\begin{array}{l}\text { Sevdiklerimle İletişim ve bağ içinde } \\
\text { olmak, }\end{array}$ & 3039 & 58,64 \\
\hline & Boş zaman faaliyeti, eğlence, & 2130 & 41,15 \\
\hline & Bilgilenme ( Spor, Diyet, Akademik) & 2109 & 40,72 \\
\hline & Yalnızlığıma iyi geliyor, & 1061 & 20,46 \\
\hline & İş gereği, & 1016 & 19,60 \\
\hline & $\begin{array}{l}\text { Yeni insanlar tanımak ve başka insanların } \\
\text { hayatını merak duygum, }\end{array}$ & 712 & 13,74 \\
\hline & $\begin{array}{l}\text { Pandemi süresince kaygımı azalttığını } \\
\text { düşünüyorum }\end{array}$ & 522 & 10,06 \\
\hline
\end{tabular}




\begin{tabular}{llcc}
\hline $\begin{array}{l}\text { Sosyal Medya } \\
\text { Kullanımı ile ilgili } \\
\text { Düşünceniz nedir? }\end{array}$ & $\begin{array}{l}\text { Bana olumsuz bir etkisinin olmadı̆̆ını } \\
\text { düsüyorum }\end{array}$ & $\mathbf{3 2 5 6}$ & $\mathbf{6 2 , 8 9}$ \\
& $\begin{array}{l}\text { Faydalı olduğunu düşünüyorum } \\
\text { Kullanım düzeyimden rahatsızım, zarar } \\
\text { verdiğini düşünüyorum, yardım almak } \\
\text { isterdim }\end{array}$ & 2931,47 \\
& $\begin{array}{l}\text { Sosyal medya hesaplarımı kapatmak } \\
\text { istiyorum }\end{array}$ & 526 & 12,15 \\
& & 529 & 10,18 \\
\hline
\end{tabular}

Tablo 2 İncelendiğinde araştırmanın bulgularına göre en fazla kullanılan sosyal medya uygulaması İnstagram $(\% 89,66)$ uygulaması olduğu görülmüştür. Fotoğraf ve video paylaşım sosyal medya aracı olan instagram, insanlara, moda, diyet, spor, hobi, e ticaret, eğitim seminer vb. konularda anlık fotoğraf ve video aracılığıyla bilgilendirme sağlaması sebebiyle en çok tercih edilen platform olduğu düşünülmektedir. Özellikle online canlı yayınlarla kişi dilediği eğitimlere de katılabilmekte, canlı müzik dinleyebilmekte ve orada etkileşime katılabilmekte olmasının da olumlu etkilerinin olduğu söylenebilir. Alanyazın incelendiğinde araştırma bulgularımızı destekler nitelikte, en fazla kullanılan sosyal medya araçlarının İnstagram, Facebook ve Twitter olduğu görülmektedir (Aslan ve Yaşar 2020; Sağar, 2019; Buluk, Eşitti ve Boz 2017)

Kırcaburun ve Griffiths (2018) gençlerde kişilik ve sosyal medya bağımlılığı ilişkisini araştırmış ve Instagram’ın bağımlılık yaratan kullanımı ve bunun altında yatan faktörleri incelenmiştir. Bireylerin kendini beğenmesine kısmen Instagram bağımlılığı ile ilişkisinin aracılık ettiği sonucuna ulaşılmıştır. Araştırmanın bulgularına göre katılımcıların sosyal medya araçlarını kullanma amaçlarında ilk sırayı "Sevdiklerimle İletişim ve bağ içinde olmak" $(\% \mathbf{5 8 , 6 4 )}$ seçeneğinin olduğu görülmüştür. İster inanın ister inanmayın, görünüşte sosyal medya insanları çevredeki insanlardan ayırıyor gibi görünse de sosyal medya dünyanın her yerinden insanları birbirine bağlıyor (Kobiruzzaman M, M. 2018). Özellikle son bir yıldır Covid 19 kaynaklı eve kapanma, sevdiklerimizden uzak kalma ve ölümlerin çok olması bu seçeneğin işaretlenmesinde oldukça etkili olmuştur.

Araştırmanın bulgularına göre katılımcıların sosyal medya araçları kullanımıyla ilgili olarak ilk sırada "Bana olumsuz bir etkisinin olmadığını düşünüyorum” $(\% 62,89)$ düşüncesinin yer aldığı görülmüştür. Katılımcıların büyük çoğunluğu sanıldığının aksine sosyal medya kullanımı ile ilgili olarak sosyal medyanın kendilerine olumsuz etkisinin olmadığını düşünmektedirler. Faydalı

Turkish Academic Research Review - Türk Akademik Araştırmalar Dergisi 
diyenlerin sayısı da hesaba katılınca genel olarak insanların sosyal medya kullanımına olumlu baktıklarını söyleyebiliriz. Zarar verdiğini düşünenlerin sayısı $(\% 12,15)$ oldukça düşük bulunmuştur. Fakat Sosyal medya kullanımı üzerine yapılan çalışmaların büyük çoğunluğu, fazla sosyal medya kullanımı ile depresyon, kaygı bozukluğu ve stres arasında pozitif yönlü ilişkiler saptamışlardır. (Elhai ve ark., 2020; Hou ve ark., 2019, Diker ve Çelik, 2021). Eroğlu ve Yıldırım (2017) üniversite öğrencileri ile yaptığı çalışmada sosyal medya kullanımı süresi ile uyku kalitesi arasında negatif ilişki olduğunu bulmuştur.

Tablo 3. Sosyal Medya Bă̆ımlılık Ölçeği Puanlarının, Katılımcıların Cinsiyeti Değişkenine Göre Farklılaşıp Farklılaşmadığını Belirlemek Üzere Yapılan Bă̆ımsız Grup t Testi Sonuçlarl

\begin{tabular}{lrccccc} 
& Cinsiyet & $N$ & $\bar{X}$ & ss & \multicolumn{1}{c}{$t$} & $p$ \\
\hline SMBÖ & Kadın & 2973 & 82,42 & 28,52 & 5,060 & $0.00^{*}$ \\
& Erkek & 2203 & 78,44 & 27,29 & & \\
\hline
\end{tabular}

Sosyal medya bağımlılık ölçeği puanlarının, katılımcıların cinsiyeti değişkenine göre farklılaşıp farklılaşmadığını belirlemek üzere yapılan bağımsız grup t testi sonuçlarına göre kadınların SMBÖ puan ortalamalarının erkeklerin puan ortalamalarından anlamlı düzeyde yüksek olduğu bulunmuştur. Bu sonuç ilgili literatür araştırmalarında beklenen bir durum olarak ele alınmaktadır. (Shaw ve Black, 2008, Kraut vd., 1998, Brys, 2013; Okumuş, 2018; Taşçı ve Ekiz 2018); kızlarda sosyal medya kullanımının yaygın olması kızların mesafe tanımaksızın arkadaşlarıyla iletişimini sürdürmek istemelerinden kaynaklandığı şeklinde ifade edilmektedir (Shaw ve Black, 2008). Aynı zamanda Bonn Üniversitesinde yapılan bir araştırma, kadınların genetik olarak bağımlılığa daha yatkın olduğuna dair kanıtlar sunmaktadır (Nakaya, 2015). Ancak yapılan bazı araştırmalarda ise cinsiyetler arasında anlamlı bir fark olmadığı da görülmektedir (Yılmazsoy ve Kahraman, 2017; Elhai vd., 2018; Akt Güney ve Taştepe 2020; Aktan (2018); Baz (2018); Gül ve Diken (2018); Sağar (2018) tarafından üniversite öğrencileri ile yapılan araştırmalarda da sosyal medya bağımlılı̆̆ı bakımından kadın ve erkekler arasında bir farkın olmadığına ulaşılmıştır.

Araştırma bulgularının tersi olarak Zorbaz ve Dost (2014) yılında yaptıkları çalışma bulguları erkek lise öğrencilerinin problemli internet kullanımı düzeylerinin kadın lise öğrencilerininkinden daha yüksek olduğunu göstermiştir. 
Sosyal Medya Bağımlılığı Ölçeğinin Değerlendirilmesine göre "74-106” puan aralığı "az bağımlı" olarak değerlendirildiğinden dolayı hem "kadın” ( $\bar{X}$ :82,42) hem de “erkek" ( $\overline{\mathrm{X}}: 78,44)$ sosyal medya kullanıcılarının bağımlı kategorisinde fakat az bağımlı olarak değerlendirilebileceğini söyleyebiliriz.

Tablo 4. Sosyal Medya Bă̆ımlılık Ölçeği Puanlarının, Katılımcıların Medeni Durum Değişkenine Göre Farklılaşıp Farklılaşmadı̆̆ını Belirlemek Üzere Yapılan Bă̆ımsız Grup t Testi Sonuçları

\begin{tabular}{lcccccc}
\hline $\begin{array}{c}\text { Sosyal Medya } \\
\text { Kullanımı }\end{array}$ & Medeni & & & & $\mathrm{t}$ & $\mathrm{p}$ \\
\hline Toplam puan & Durumunuz? & $\mathrm{N}$ & $\bar{X}$ & ss & & \\
& Evli & 2380 & 73,26 & 24,86 & $-18,21$ & $0.00^{*}$ \\
& Bekar & 2796 & 87,08 & 29,06 & &
\end{tabular}

Sosyal medya bağımlılık ölçeği puanlarının, katılımcıların medeni durum değişkenine göre farklılaşıp farklılaşmadığını belirlemek üzere yapılan bağımsız grup t testi sonuçlarına göre bekarların SMBÖ puan ortalamalarının evlilerin puan ortalamalarından anlamlı düzeyde yüksek olduğu bulunmuştur.

Sosyal Medya Bağımlılığı Ölçeğinin Değerlendirilmesine göre “74-106” puan aralığı "az bağımlı" olarak değerlendirildiğinden dolayı "bekar" sosyal medya kullanıcılarının ( $\overline{\mathrm{X}}:$ 87,08) bağımlı kategorisinde fakat az bağımlı olarak değerlendirilebileceği; “evli” sosyal medya kullanıcılarının ise (41-73 Bağımlılık Yok; $\bar{X}$ : 73,26) bağımlı olmadıklarını söyleyebiliriz. Anlı (2018) İnternet bağımlılığı ile sosyal ve duygusal yalnızlık arasındaki ilişkiyi incelemek amacıyla yaptığı araştırma sonucunda İnternet bağımlılığının; sosyal ilişkilerde yalnızlık, duygusal ilişkilerde yalnızlık ve aile ilişkilerinde yalnızlık ile pozitif yönlü olarak ilişkili olduğu tespit edilmiştir (Akt.Koca, Tunca 2019)

Tablo 5.1. SMBÖ Puanlarının Yaş Değişkenine Göre Farklılaşıp Farklılaşmadı̆̆ını Belirlemek Üzere Yapılan Tek Yönlü Varyans Analizi (ANOVA) Sonuçları

\begin{tabular}{|c|c|c|c|c|c|c|c|c|c|c|}
\hline & Grup & $N$ & $\bar{X}$ & $s S$ & $\begin{array}{l}\text { Var. } \\
\text { K. }\end{array}$ & $K T$ & $S d$ & $K O$ & $F$ & $p$ \\
\hline & $14-18 * *$ & 816 & 91,75 & 30,93 & $\begin{array}{l}\text { G. } \\
\text { Aras1 }\end{array}$ & 373434,29 & 5 & 74686,859 & & \multirow{5}{*}{$.000 *$} \\
\hline \multirow{4}{*}{ SMBÖ } & $19-25^{* *}$ & 1247 & 88,92 & 28,39 & G.İ̧i & 3704678,73 & 5170 & 716,572 & \multirow{4}{*}{104,228} & \\
\hline & $26-35^{* *}$ & 1472 & 79,57 & 26,67 & Toplam & 4078113,28 & 5175 & & & \\
\hline & $\begin{array}{l}36- \\
45^{* * *}\end{array}$ & 1079 & 70,48 & 23,45 & & & & & & \\
\hline & $46-$ & 505 & 68,81 & 21,91 & & & & & & \\
\hline
\end{tabular}

Turkish Academic Research Review - Türk Akademik Araştırmalar Dergisi 


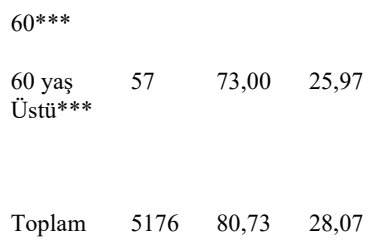

* (p<.05);**Az Bağıml $\bar{X}: 74-106 ; * * *$ Bă̆ımlılık Yok; $\bar{X}: 41-73$

Tablo 5.2. SMBÖ Puanlarının Yaş Değişkenine Göre Hangi Alt Gruplar Arasında Farklılaştığını Belirlemek Üzere Yapılan Tek Yönlü Varyans Analizi (ANOVA) Sonrası Scheffe Testi Sonuçları

\begin{tabular}{|c|c|c|c|}
\hline (I) Yaş & (J) Yaş & (I-J) & $\mathbf{p}$ \\
\hline \multirow[t]{5}{*}{$14-18$ yaş } & $19-25$ yaş & 2,82425 & ,177 \\
\hline & 26-35 yaş & $12,17827^{*}$ & ,000 \\
\hline & $36-45$ yaş & $21,27360^{*}$ & ,000 \\
\hline & 46-60 yaş & $22,93982^{*}$ & ,000 \\
\hline & 60 yaş Üstü & $18,75368^{*}$ &, 000 \\
\hline \multirow[t]{5}{*}{$19-25$ yaş } & 14-18 yaş & $-2,82425$ & , 177 \\
\hline & 26-35 yaş & $9,35402^{*}$ & ,000 \\
\hline & $36-45$ yaş & $18,44936^{*}$ & ,000 \\
\hline & 46-60 yaş & $20,11557^{*}$ & ,000 \\
\hline & 60 yaş Üstü & $15,92943^{*}$ & ,000 \\
\hline \multirow[t]{5}{*}{$26-35$ yaş } & 14-18 yaş & $-12,17827^{*}$ & ,000 \\
\hline & $19-25$ yaş & $-9,35402^{*}$ & ,000 \\
\hline & $36-45$ yaş & $9,09533^{*}$ & ,000 \\
\hline & 46-60 yaş & $10,76155^{*}$ & ,000 \\
\hline & 60 yaş Üstü & 6,57541 & ,453 \\
\hline \multirow[t]{5}{*}{ 36-45 yaş } & 14-18 yaş & $-21,27360^{*}$ & ,000 \\
\hline & $19-25$ yaş & $-18,44936^{*}$ & ,000 \\
\hline & $26-35$ yaş & $-9,09533^{*}$ & ,000 \\
\hline & 46-60 yaş & 1,66621 & ,858 \\
\hline & 60 yaş Üstü & $-2,51993$ & ,983 \\
\hline \multirow[t]{5}{*}{$46-60$} & 14-18 yaş & $-22,93982^{*}$ & ,000 \\
\hline & $19-25$ yaş & $-20,11557^{*}$ &, 000 \\
\hline & $26-35$ yaş & $-10,76155^{*}$ & ,000 \\
\hline & 36-45 yaş & $-1,66621$ & ,858 \\
\hline & 60 yaş Üstü & $-4,18614$ &, 874 \\
\hline \multirow[t]{5}{*}{60 yaş Üstü } & $14-18$ yaş & $-18,75368^{*}$ &, 000 \\
\hline & $19-25$ yaş & $-15,92943^{*}$ & ,000 \\
\hline & $26-35$ yaş & $-6,57541$ & ,453 \\
\hline & 36-45 yaş & 2,51993 & ,983 \\
\hline & 46-60 yaş & 4,18614 & ,874 \\
\hline
\end{tabular}

Tablo 5.1 ve 5.2 incelendiğinde, 14-18 yaş ile 19-25 yaşlar arası ve 60 yaş üstü ile 26-35 arası yaş, 36-45 arası yaş ve 46-60 arası yaşlar arasında anlamlı düzeyde fark çıkmamıştır ( $\mathrm{p}>.05)$. Geriye kalan tüm yaş grupları arasında Tablo 
5.2.' de görüldüğü gibi anlamlı düzeyde fark çıkmıştır $(\mathrm{p}<.01)$. Sosyal Medya Bağımlılığı Ölçeğinin Değerlendirilmesine göre "74-106” puan aralığı "az bağımlı" olarak değerlendirildiğinden dolayı 14-35 yaş arası katılımcıların az bağımlı oldukları söylenebilir. Fakat en yüksek puanın 14-18 yaş aralığında ile $(\overline{\mathrm{X}}: 91,75)$ ve en düşük puanın 46-60 yaş aralığında $(\overline{\mathrm{X}}: 68,81)$ olduğu görülmektedir. Sadece 1418 ( $\overline{\mathrm{X}}:$ 32.13) ile 19- 25 ( $\overline{\mathrm{X}}:$ 32.03) yaşlar arası SMBÖ alt puanlarından "Meşguliyet” sosyal medyanın kişiyi meşgul etme etkisini ölçümlerinde diğer yaş gruplarından anlamlı düzeyde daha yüksek çıkmış ve "32-41 Orta Bağımlı "kategorisinde değerlendirilmiştir. Araştırmanın bulgularına göre SMBÖ toplam puan verilerinde 36 yaş ve üzeri yaş katılımcıların bağımlılık yok kategorisinde değerlendirilebileceği söylenebilir. Deniz ve Gürültü (2018) lise öğrencilerinin sosyal medya bağımlılıkları üzerine yaptığı çalışmada, lise öğrencilerinin sosyal medyaya orta seviyede bağımlı olduğu tespit edilmiştir.

Yaş ilerledikçe bağımlılığında azaldığını söyleyebiliriz fakat özellikle 60 yaş üstünde az da olsa puanlarda bir artışın olmasını $(\overline{\mathrm{X}}: 73,00)$ emeklilikle beraber boş zaman faaliyetlerinde artış, yalnızlık duyguları, uzaktaki sevdikleri ile bağ içinde olma ve haberdar olma isteklerinden kaynaklı olduğu söylenebilir.

Tablo 6.1 SMBÖ Puanlarının Eğitim Durumu Değişkenine Göre Farklılaşıp Farklılaşmadığını Belirlemek Üzere Yapılan Tek Yönlü Varyans Analizi (ANOVA) Sonuçları

\begin{tabular}{|c|c|c|c|c|c|c|c|c|c|c|}
\hline & Grup & $N$ & $\bar{X}$ & ss & Var. K. & $K T$ & $S d$ & $K O$ & $F$ & $p$ \\
\hline & İlkokul*** & 75 & 71,92 & 24 & G. Aras1 & 81636,63 & 5 & 16327,32 & & \\
\hline $\begin{array}{l}\mathbf{S} \\
\mathbf{M}\end{array}$ & Ortaokul** & 100 & 77,14 & 29,13 & G.İçi & 3996476,39 & 5170 & 773,01 & & \\
\hline B & Lise** & 1105 & 88,04 & 30,28 & Toplam & 4078113,28 & 5175 & & 21,12 & $.00 *$ \\
\hline & Üniversite & 3228 & 79,28 & 27,13 & & & & & & \\
\hline & $\begin{array}{l}\text { Yüksek** } \\
\text { Lisans** }\end{array}$ & 506 & 77,08 & 26,38 & & & & & & \\
\hline & Doktora** & 162 & 77,27 & 28,39 & & & & & & \\
\hline & Toplam** & 5176 & 80,73 & 28,07 & & & & & & \\
\hline
\end{tabular}

Turkish Academic Research Review - Türk Akademik Araştırmalar Dergisi https://dergipark.org.tr/tr/pub/tarr 
Tablo 6.2 SMBÖ Puanlarının Eğitim Düzeyi Değişkenine Göre Hangi Alt Gruplar Arasında Farklılaştığını Belirlemek Üzere Yapılan Tek Yönlü Varyans Analizi (ANOVA) Sonrası Scheffe Testi Sonuçları

\begin{tabular}{cccc}
\hline (I) Öğrenim Durumu & (J) Öğrenim Durumu & $(\mathrm{I}-\mathrm{J})$ & $\mathrm{p}$ \\
\hline & İlkokul & $\mathbf{1 6 , 1 2}^{*}$ & $\mathbf{0 0 0}$ \\
Lrta okul & $\mathbf{1 0 , 9 0}^{*}$ & $\mathbf{0 1 5}$ \\
& Üniversite & $\mathbf{8 , 7 5}^{*}$ & $\mathbf{0 0 0}$ \\
& Yüksek lisans & $\mathbf{1 0 , 9 6}^{*}$ & $\mathbf{0 0 0}$ \\
& Doktora & $\mathbf{1 0 , 7 7 4 5 5}^{*}$ & $\mathbf{, 0 0 1}$ \\
\hline
\end{tabular}

$(\mathrm{p}<.01)$

Tablo 6.1 ve 6.2 incelendiğinde, Sadece lise eğitim düzeyi ile tüm eğitim düzeyleri arasında anlamlı düzeyde fark çıkmıştır( $(\mathrm{p}<.01)$. Geriye kalan tüm eğitim düzeyleri arasında ise anlamlı düzeyde fark çıkmamıştır(p>.05). Her ne kadar Lise eğitim düzeyi ile ortaokul, üniversite, yüksek lisans ve doktora eğitim düzeyleri "74106" puan aralığı "az bağımlı" olarak değerlendirilse de Lise eğitim düzeyinin anlamlı düzeyde diğerlerinden farklılaştığı görülmektedir.

Sosyal Medya Bağımlılığı Ölçeğinin Değerlendirilmesine göre "74-106” puan aralığı "az bağımlı" olarak değerlendirildiğinden dolayı tüm yaş aralıklarının ölçekten aldıkları puanlar göz önüne alındığında İlkokul (41-73 Bağımlılık Yok; $\bar{X}$ : $71,92)$ hariç diğer tüm eğitim düzeyleri "az bağımlı” olarak değerlendirilebilir.

Tablo 7.1 SMBÖ Puanlarının Meslek Değişkenine Göre Farklılaşıp Farklılaşmadığını Belirlemek Üzere Yapılan Tek Yönlü Varyans Analizi (ANOVA) Sonuçları

\begin{tabular}{|c|c|c|c|c|c|c|c|c|c|c|}
\hline & Grup & $N$ & $\bar{X}$ & ss & Var. K. & $K T$ & $S d$ & $K O$ & $F$ & $p$ \\
\hline & Memur** & 864 & 75,46 & 25,93 & G. Aras1 & 265264,95 & 10 & 26526,5 & & \\
\hline & İşçi $* *$ & 276 & 76,96 & 24,48 & G.İçi & 3812848,8 & 5165 & 738,20 & & \\
\hline & Çiftçi ** & 22 & 81,72 & 30,30 & Toplam & 4078113,02 & 5175 & & & \\
\hline & Esnaf*** & 141 & 69,68 & 20,18 & & & & & & \\
\hline \multirow{9}{*}{$\begin{array}{l}\mathbf{S} \\
\mathbf{M} \\
\mathbf{B} \\
\ddot{\mathbf{O}}\end{array}$} & Öğretmen/ & 1350 & 75,12 & 26 & & & & & 35,93 & $.00 *$ \\
\hline & $\begin{array}{l}\text { Akademisyen* } \\
*\end{array}$ & & & & & & & & & \\
\hline & Öğrenci** & 1696 & 90,23 & 29,70 & & & & & & \\
\hline & Emekli** & 85 & 75,81 & 25,16 & & & & & & \\
\hline & Avukat** & 14 & 82,21 & 31,45 & & & & & & \\
\hline & Özel Sektör** & 195 & 74,64 & 23,45 & & & & & & \\
\hline & $\begin{array}{l}\text { Serbest } \\
\text { Meslek*** }\end{array}$ & 111 & 70,64 & 26,94 & & & & & & \\
\hline & Çalışmıyor** & 422 & 83,76 & 28,01 & & & & & & \\
\hline & Total & 5176 & 80,73 & 28,07 & & & & & & \\
\hline
\end{tabular}


Tablo 7.2. SMBÖ Puanlarının Meslek Değişkenine Göre Hangi Alt Gruplar Arasında Farklılaştığını Belirlemek Üzere Yapılan Tek Yönlü Varyans Analizi (ANOVA) Sonrası Scheffe Testi Sonuçları

\begin{tabular}{|c|c|c|c|}
\hline (I) Meslek & (J) Mesleğiniz & $(\mathrm{I}-\mathrm{J})$ & Sig. \\
\hline \multirow[t]{10}{*}{ Öğrenci } & Memur & $14,77^{*}$ & ,000 \\
\hline & İşçi & $13,27^{*}$ &, 000 \\
\hline & Çiftçi & 8,50 & ,995 \\
\hline & Esnaf & $20,55^{*}$ & ,000 \\
\hline & Öğretmen/ Akademisyen & $15,11^{*}$ & ,000 \\
\hline & Emekli & $14,42^{*}$ & ,012 \\
\hline & Avukat & 8,02 & 1,00 \\
\hline & Özel Sektör & $15,59^{*}$ & ,000 \\
\hline & Serbest Meslek & $19,58^{*}$ &, 000 \\
\hline & Çalışmıyor & $6,46^{*}$ & ,039 \\
\hline \multirow[t]{10}{*}{ Çalışmıyor } & Memur & $\mathbf{8 , 3 0 *}$ &, 00 \\
\hline & İşçi & 6,80 &, 40 \\
\hline & Çiftçi & 2,04 & 1,00 \\
\hline & Esnaf & $14,08^{*}$ & ,00 \\
\hline & Öğretmen/ Akademisyen & $8,64^{*}$ & ,00 \\
\hline & Öğrenci & $-6,46^{*}$ & ,03 \\
\hline & Emekli & 7,95 &, 81 \\
\hline & Avukat & 1,55 & 1,00 \\
\hline & Özel Sektör & 9,12 & ,13 \\
\hline & Serbest Meslek & $13,11^{*}$ &, 02 \\
\hline
\end{tabular}

$(\mathrm{p}<.05)$

Tablo 7.1 ve 7.2.de mesleklere göre SMBÖ puanları incelendiğinde; öğrenci mesleği SMBÖ puanları ( $\overline{\mathrm{X}}:$ 90,23) ile Çif̧ci ve Avukat meslekleri SMBÖ puanları arasında anlamlı düzeyde fark çıkmamıştır(p>.05). "Öğrenci” meslek seçeneği lehine SMBÖ puanları ile diğer tüm meslekler SMBÖ puanları arasında anlamlı düzeyde fark çıkmıştır( $<$ <.01). Bu durum hem onların genç yaşta olması ile hem de eğitim aracı olarak pandemi döneminde bilgiye ulaşma, okul ve sınıf arkadaşları ile bağ içinde olma bakımından, zamanlarının daha fazla bir bölümünü sosyal medya mecralarında geçirmelerine yol açtığı düşünülebilir. Yine Çalışmıyor kategorisi katılımcılarının lehine SMBÖ puanları ile Memur, Esnaf, Öğretmen/ Akademisyen ve Serbest Meslek SMBÖ puanları arasında anlamlı düzeyde fark 
çıkmıştır(p<.01). Diğer tüm meslekler SMBÖ puanları arasında anlamlı düzeyde bir fark görülmemiştir.

Sosyal Medya Bağımlılığı Ölçeğinin Değerlendirilmesine göre “74-106” puan aralığı "az bağımlı" olarak değerlendirildiğinden dolayı, Esnaf (41-73 Bağımlılık Yok; $\bar{X}: 71,92)$ ve serbest meslek (41-73 Bağımlılık Yok; $\bar{X}: 69,68$ hariç diğer tüm Meslek SMBÖ puan düzeyleri "az bağımlı" olarak değerlendirilebilir.

Müezzin (2017) lise öğrencilerinin internet ve sosyal medya bağımlılığının, yoksunluk, kontrol güçlüğü, işlevsellikte bozulma ve sosyal izolasyon bağlamında öğrencilerin büyük bir bölümünün risk ve eşik grubunda olduğu sonucuna varılmıştır. Şahan ve Eraslan Çapan (2017)'ın yaptığı çalışma sonucuna göre ergenlerin sosyal medya ve internet kullanım süreleri ile kişilerarası ilişkilerle ilgili bilişsel çarpıtmalar arasında negatif yönlü ilişki olduğunu saptanmıştır.

Tablo 8.1. Günlük sosyal medya kullanım süresi Bilgileri f, \% tablosu

\begin{tabular}{crrr}
\hline $\begin{array}{l}\text { Günlük sosyal medya } \\
\text { kullanım süresi }\end{array}$ & f & \multicolumn{1}{c}{$\%$} & Toplamalı $\%$ \\
\hline 1 saatten az & 929 & 17,9 & 17,9 \\
1-3 saat aras1 & $\mathbf{2 7 8 7}$ & $\mathbf{5 3 , 8}$ & 71,8 \\
4-6 saat aras1 & 1173 & 22,7 & 94,5 \\
7 saat ve üzeri & 287 & 5,5 & 100,0 \\
Total & 5176 & 100,0 & \\
\hline
\end{tabular}

Tablo 8.1. İncelendiğinde Günlük sosyal medya kullanım süresine göre katılımcıların en çok işaretlediği seçenek günlük 1-3 saat (f:929; \%53,8) geçirilen süre seçeneğidir.

Literatürde İnternet ve sosyal medyanın aşırı ya da problemli kullanılması ve haftanın en az 8,5 ile 21,5 saatinin çevrimiçi geçirilmesi) bağımlılık olarak değerlendirilmektedir (Young, 2007, Yang ve Tung, 2007). Bu bağlamda değerlendirildiğinde katılımcıların 76,5' i bağımlı ve 5,5 'i aşırı bağımlı olduğu ve toplamda \%82'i bağımlı diyebiliriz. En yüksek kullanım aralığı olarak 1-3 saat arası bulgusu literatüre göre beklenen bir sonuçtur. Öğrencilerin sosyal medyayı ne kadar süredir kullandıkları sorusuna verdikleri yanıtlar ışığında kullanım yılının artması durumunda literatüre benzer olarak sosyal medya bağımlılık düzeylerinin de arttı̆̆1 görülmüştür (Aktan, 2018; Balcı ve Gölcü, 2013 Solmaz ve ark, Baz 2018). 
Tablo 8.2. SMBÖ Puanlarının Günlük Sosyal Medya Kullanım Süresi Değişkenine Göre Hangi Alt Gruplar Arasında Farklılaştığını Belirlemek Üzere Yapılan Tek Yönlü Varyans Analizi (ANOVA) Sonrası Tukey HSD Testi Sonuçları

\begin{tabular}{|c|c|c|c|}
\hline $\begin{array}{l}\text { (I) Günlük sosyal medya } \\
\text { kullanım süresi }\end{array}$ & $\begin{array}{l}\text { (J) Günlük sosyal medya } \\
\text { kullanım süresi }\end{array}$ & $(\mathrm{I}-\mathrm{J})$ & $\mathrm{p}$ \\
\hline \multirow{3}{*}{1 saatten az } & $1-3$ saat arası & $-17,22^{*}$ &, 000 \\
\hline & 4-6 saat aras1 & $-36,50^{*}$ & ,000 \\
\hline & 7 saat ve üzeri & $-54,05^{*}$ &, 000 \\
\hline \multirow[t]{3}{*}{$\overline{1-3 \text { saat aras1 }}$} & 1 saatten az & $17,22^{*}$ & ,000 \\
\hline & 4-6 saat aras1 & $-19,28^{*}$ & ,000 \\
\hline & 7 saat ve üzeri & $-36,83^{*}$ &, 000 \\
\hline \multirow[t]{3}{*}{ 4-6 saat arası } & 1 saatten az & $\mathbf{3 6 , 5 0} 0^{*}$ & ,000 \\
\hline & $1-3$ saat arası & $19,28^{*}$ & ,000 \\
\hline & 7 saat ve üzeri & $-17,55^{*}$ & ,000 \\
\hline \multirow[t]{3}{*}{7 saat ve üzeri } & 1 saatten az & $54,05^{*}$ & ,000 \\
\hline & $1-3$ saat aras 1 & $36,83^{*}$ &, 000 \\
\hline & 7 saat ve üzeri & $17,55^{*}$ &, 000 \\
\hline
\end{tabular}

Tablo 8.3. SMBÖ Puanlarının Günlük Sosyal Medya Kullanım Süresi Değişkenine Göre Farklılaşıp Farklılaşmadı̆̆ını Belirlemek Üzere Yapılan Tek Yönlü Varyans Analizi (ANOVA) Sonuçları

\begin{tabular}{|c|c|c|c|c|c|c|c|c|c|c|}
\hline & Grup & $N$ & $\overline{\bar{X}}$ & ss & $\begin{array}{l}\text { Var. } \\
\text { K. }\end{array}$ & $K T$ & $S d$ & $K O$ & $F$ & $p$ \\
\hline $\begin{array}{l}\text { S } \\
\text { M }\end{array}$ & 1 saatten az & 929 & 60,18 & $\begin{array}{l}16,9 \\
8\end{array}$ & $\begin{array}{l}\text { G. } \\
\text { Aras1 }\end{array}$ & $\begin{array}{l}1043891,5 \\
2\end{array}$ & 3 & $\begin{array}{l}347963,8 \\
4\end{array}$ & & \\
\hline $\begin{array}{l}\text { B } \\
\ddot{O}\end{array}$ & $\begin{array}{l}\text { 1-3 saat } \\
\text { arası }\end{array}$ & $\begin{array}{l}278 \\
7\end{array}$ & 77,40 & $\begin{array}{l}23,9 \\
9\end{array}$ & G.İçi & $\begin{array}{l}3034221,5 \\
0\end{array}$ & $\begin{array}{l}517 \\
2\end{array}$ & 586,66 & $\begin{array}{c}593,1 \\
2\end{array}$ & 0 \\
\hline & $\begin{array}{l}\text { 4-6 saat } \\
\text { arası }\end{array}$ & $\begin{array}{l}117 \\
3\end{array}$ & 96,69 & $\begin{array}{l}27,2 \\
4\end{array}$ & $\begin{array}{l}\text { Topla } \\
\text { m }\end{array}$ & $\begin{array}{l}4078113,0 \\
2\end{array}$ & $\begin{array}{l}517 \\
5\end{array}$ & & & $\begin{array}{l}\mathbf{0} \\
*\end{array}$ \\
\hline & $\begin{array}{l}7 \text { saat ve } \\
\text { üzeri }\end{array}$ & 287 & $\begin{array}{l}114,2 \\
4\end{array}$ & $\begin{array}{l}31,9 \\
5\end{array}$ & & & & & & \\
\hline
\end{tabular}

$(\mathrm{p}<.05)$

Tablo 8.2 ve 8.3 incelendiğinde, günlük sosyal medya kullanım süresi “1 saatten az" kategorisini işaretleyenlerin ölçekte belirtilen (41-73 Bağımlılık Yok; $\bar{X}$ : $60,18)$ puan değerlerine göre bağımlılıklarının olmadığını söyleyebiliriz. Ölçekten aldıkları puan ile bu soruda seçim olarak belirttikleri arasında uygunluk olduğu görülmektedir. Ölçekten alınan puanlar arttıkça kişilerin sosyal medya kullanım sürelerinin arttığ1 görülmektedir. 1-3 saat arası $(\overline{\mathrm{X}}: 77,40)$ ile 4-6 saat arası $(\overline{\mathrm{X}}$ : 96,69) "74-106” puan aralığı "az bağımlı" olarak değerlendirilebilir. 7 Saat ve üzeri sosyal medya kullanım süresi olan kişilerin (X): 114,24) orta bağımlı (107-139)

Turkish Academic Research Review - Türk Akademik Araştırmalar Dergisi 
olarak değerlendirilebilir. Sosyal medyayı günlük kullanım süresinin artması durumunda ve aktif olarak kullanılan sosyal medya hesap sayısında artış olması durumunda öğrencilerin sosyal medya bağımlılık düzeyleri de artmaktadır (Alican ve Saban, 2013; Çiftçi, 2018; Güler ve ark, 2019).

\section{TARTIŞMA}

Günümüzde internetin hayatımızın vazgeçilmez bir parçası haline gelmesi ve beraberinde mobil telefonlar ile internete erişim, sosyal medya uygulamalarının yaygınlaşması bir gerçektir. İlgili araştırmalara bakıldığında internet ve sosyal medyanın olumsuz kullanımına yönelik araştırmalar daha fazla yer almaktadır. Fakat bizim araştırmamızda oldukça fazla sayılacak 5176 kişiden elde edilen veriler gösteriyor ki, insanlar genel olarak "sosyal medya kullanmaktan rahatsız değilim" \%62,89 ve aynı zamanda "faydalı buluyorum" diyenler \%30 düzeyinde. "Kullanım düzeyimden rahatsızım, zarar verdiğini düşünüyorum, yardım almak isterdim" diyenlerin sadece \%12,15 olması dikkat çekicidir. Kullanım amaçları da incelendiğinde bulgularda ilk sırayı "sevdiklerimle iletişim ve bağ içerisinde olmak" \% 58.64 ibaresin aldığını görüyoruz Nitekim bulgular incelendiğinde Boş zaman faaliyeti, eğlence, Bilgilenme ( Spor, Diyet, Akademik) Yalnızlığıma iyi geliyor, İş gereği, (\%42 -\%20 aralığında ) ibarelerinin de azımsanmayacak oranda tercih edildiğini görebiliriz.

Özellikle tüm dünyada Covid 19 pandemi süreciyle beraber eve kapanma, sosyal mesafe, sevdiklerinden uzak kalma ve sevdiklerinin sağlığg ile ilgili kaygılar; uzaktan eğitim ve ekran ilişkisi insanları daha fazla internet ve sosyal medya kullanımına itti. $\mathrm{Bu}$ durumdan insanların şikayetçi olmadığını tersine sosyal medyanın kendilerine katkısı olduğunu belirtmişlerdir.

Sosyal medya bağımlılı̆̆ puanları yaş attıkça azalmış fakat emeklilik az da olsa bir artış göstermiştir. On dörtlü yaşlarla beraber yoğun kullanımın, yirmili yaşlarla beraber iş hayatına atılma ve meşguliyetin artması, otuzlu, kırklı ve ellili yaşlarla yaşlarda sosyal medya kullanımının azaldığını bağımlılı̆̆ın olmadığını görüyoruz. Fakat emeklilik sonra yeniden az bağımlı düzeyde sosyal medya kullanımın olduğunu söyleyebiliriz. Bu durumun sebebi olarak 65 yaş üstü sokağa çıkma yasaklarının olması ve emeklilikten dolayı meşguliyet azlığı olabilir.

Sosyal medya bağımlılığı puanları en yüksek öğrenci-14-18 yaşlar ve işsiz(çalışmayan) kesimde çıkmıştır (ölçeğin değerlendirmesine göre az bağımlı 
kategorisinde yer almaktalar). Öğrencilerin yoğun sosyal medya kullanımı neredeyse tüm araştırmalarda rapor edilmiştir. Daha önce sebeplerine değinmiştik. Öncelikle uzaktan eğitim süreci ve ekrana bağımlı hale gelmesi, çoğu öğrenciyi cep telefonundan derslere girmeye itmiştir. Yine işsiz çalışmayan kesiminde öğrencilerle beraber yüksek SMBÖ puanı almasında boş zaman fazlalığı, iş olanakları araştırma ve insanlarla bağ içinde olma isteğinin olduğu söylenebilir.

Sosyal medya bağımlılığı puanları ile sosyal medyada geçirilen süre arasında pozitif ilişki olduğu görülmüş. Beklenen bir sonuçtur, geçirilen sürenin artması bağımlılığı da arttıracaktır. Özellikle gençlerde bağımlılığı önleyebilmek için sosyal medya da geçirilen sürenin azaltılmasına yönelik yetişkin yönlendirme ve yardımlar önemli olacaktır.

Evlilerin, çoğu çiftin çocuklarıyla beraber eşler olarak daha az yalnızlık hissettiği malumdur. Araştırmamızda sosyal medya bağımlılığı puanlarının bekarlarda evlilere göre daha yüksek olduğu görülmüştür. Sebepleri olarak; bekarların flört ve eş seçme ihtiyaçları, yalnızlık çekmeleri, daha fazla boş zaman sahibi olmaları, beğenme ve beğenilme ihtiyaçlarının daha yüksek olması denilebilir.

Araştırmanın bulgularında sosyal medya bağımlılı̆g puanlarının kadınlarda erkeklere nazaran daha yüksek olduğu görülmüştür. Özellikle İnstagram üzerinde moda, diyet, sağlıklı beslenme ve alışverişin önemli bir yer tutması kadınların bu alana daha fazla rağbet göstermiş olmasına mantıklı bir açıklama getirecektir. Bahsettiğimiz alanlara bilindiği üzere kadınların erkeklere göre daha ilgili oldukları söylenebilir. Yine kadın beyni ve erkek beyni ile ilgili verilerde kadınların erkeklere nazaran beyinlerindeki iletişim kurma ile ilgili kısımların anne karnında itibaren daha gelişmiş olduğu, sevdikleriyle daha fazla iletişim ve bağ içinde olma isteklerini, sosyal medya kullanımlarını bize açıklamaktadır.

$\mathrm{Bu}$ araştırma göstermiştir ki, yoğun kullanım olarak sosyal medya hayatın vazgeçilmezleri arasında yerini almıştır. Devletlerin, bakanlıkların yapması gereken; bireylere gelişimleri, eğitimleri, aile ve ilişkilerini geliştirici daha yararlı sosyal medya içeriklerinin üretilmesidir. 2021 yılı içerisinde MEB ve Diyanet İşleri Başkanlığının herkese açık, uzmanlardan online seminerler vermeleri güzel örneklerdir.

Gençlerin kullanımlarını tümden yasaklamak yerine, kontrollü bir şekilde yönlendirmek, etkili kullanımını sağlamak onların gelişimleri için önemli olacaktır.

Turkish Academic Research Review - Türk Akademik Araştırmalar Dergisi https://dergipark.org.tr/tr/pub/tarr 


\section{Kaynakça}

Ağyar Bakır, B., \& Uzun, B. (2018). Developing the Social Media Addiction Scale: Validity and reliability studies. Addicta: The Turkish Journal on Addictions. Advance online publication.

http://dx.doi.org/10.15805/addicta.2018.5.3.0046

Alican, C. ve Saban, A. (2013). Ortaokul ve lisede öğrenim gören öğrencilerin sosyal medya kullanımına ilişkin tutumları: Ürgüp örneği. Sosyal Bilimler Enstitüsü Dergisi, 35(2), 1-14.

Aktan, E. (2018). Üniversite Öğrencilerinin Sosyal Medya Bağımlılık Düzeylerinin Çeşitli Değişkenlere Göre İncelenmesi. Erciyes İletişim Dergisi, 5(4), 405421.

Anlı, G. (2018). “İnternet Bağımlılığı: Sosyal ve Duygusal Yalnızlık”, Uluslararası Bilimsel Araştırmalar Dergisi, 3(2): 389-397. ki bulmuştur.

Anderson, M., \& Jiang, J. (2018). Teens, social media \& technology 2018.

Aslan İmran. (2020) Socıal Medıa Addıctıon And Controllıng Socıal Medıa Use: An Extensıve Study, Academic Studies in Social, Human and Administrative Sciences - I, Volume 1 Publisher: Gece Publishing

Aslan, İmran. M.E. Yaşar. (2020). Measurıng Socıal Medıa Addıctıon Amonguniversity

StudentsInternational Journal of Contemporary Economics and Administrativ e Sciences ISSN: 1925 - 4423Volume: X, Issue: 2, Year: 2020, pp. 468-492

Balc1, Ş. ve Gölcü, A. (2013). Facebook Addiction among University Students in Turkey: Selcuk University Example. Türkiyat Araştırmaları Dergisi (34), 255- 278 .

Baripoğlu, S. (2012). Facebook ve Twitter davranış bozukluğu yapıyor mu? epsikiyatri. Erişim adresi: http://www.e-psikiyatri.com/facebook-ve-twitterdavranis-bozukluguyapiyor-mu-33945

Baz, F. (2018). Sosyal Medya Bağımlılığı: Üniversite Öğrencileri Üzerine Çalışma. OPUS Uluslararası Toplum Araştırmaları Dergisi, 9 (16), 276-295. DOI: 10.26466/opus. 470118

Buluk B., Eşitti B., Boz M. (2017). Sosyal Medyanın Kullanım Amaçları: Üniversite Çalışanları Örneği Avrasya Uluslararası Araştırmalar Dergisi, Cilt.5, Sa.10, Ss.219-234, 2017 
Büyükaslan, A., ve A. M. Kırık (Ed.). (2015). Sosyalleşen Olgular Sosyal Medya Araştırmaları-2. İstanbul: Çizgi Kitabevi.

Brys, S. (2013). Internet addiction treatment programs on the rise. https://www.psychcongress.com/article/internet-addiction-treatmentprograms-rise (erişim tarihi: 06.03.2021).

Çakır, Ö, Ayas, T, Horzum, M. (2011). An investigation of university students' internet and game addiction with respect to several variables. Ankara University Journal of Faculty of Educational Sciences (JFES), 44 (2) , 95-118 . DOI: 10.1501/Egifak_0000001226

Çiftçi, H. (2018). Üniversite Öğrencilerinde Sosyal Medya Bağımlılığı. MANAS Sosyal Araştırmalar Dergisi, 7(4), 417-434.

Deniz, L. Ve Gürültü, E. (2018). "Lise Öğrencilerinin Sosyal Medya İnternet ve Sosyal Medya Bağımlılıkları" Kastamonu Education Journal, 26(2): 355-367.

Diker Ersin, Fatih Çelik (2021.) Covid-19 Sürecinde Depresyon, Stres, Gelişmeleri Kaçırma Korkusu Ve Zorlayıcı Sosyal Medya Kullanımı Arasındaki İlişkilerayna Klinik Psikoloji Dergisi, 2021, 8(1), 17 - 43

Eroğlu, O. Ve Yıldırım, Y. (2017). "Sosyal Medya Ağlarının Kullanım Amacı Ve Bağımlılı̆ıının Uyku Kalitesi İle İlişkisinin İncelenmesi”, Türkiye Spor Bilimleri Dergisi, 1(1): 1-10.

Elhai, J. D., Hall, B. J., Erwin, M. C. (2018). Emotion regulation's relationships with depression, anxiety and stress due to imagined smartphone and social media loss. Psychiatry Research; 261: 28-34.

Gül, Ş., Diken, E. H. (2018). Fen Bilgisi Öğretmeni Adaylarının Sosyal Medya Bağımlılıklarının İncelenmesi. Kafkas Üniversitesi, e - Kafkas Eğitim Araştırmaları Dergisi, 5(1), 41-50.

Güler, E. Ö., D, Veysikarani, D. Keskin (2019). Üniversite Öğrencilerinin Sosyal Medya Bağımlılı̆̆ı Üzerine Bir Araştırma Çağ Üniversitesi Sosyal Bilimler Dergisi Cilt 16, Sayı 1, Ss.1-13, 2019 Issn:1304-8392

Güney, M, Taştepe, T. (2020). Ergenlerde Sosyal Medya Kullanımı ve Sosyal Medya Bağımlılığı. Ankara Sağlık Bilimleri Dergisi, 9 (2) , 183-190 . Retrieved from https://dergipark.org.tr/tr/pub/ausbid/issue /59001/757713 
Griffiths, M. (1999). Violent video games and aggression: A review of the literature. Aggression and Violent Behavior, 4(2), 203212. https://doi.org/10.1016/S1359-1789(97)00055-4

Hou, Y., Xiong, D., Jiang, T., Song, L., \& Wang, Q. (2019). Social media addiction: Its impact, mediation, and intervention. Cyberpsychology: Journal of Psychosocial Research on Cyberspace, 13(1), 1-18.

Jingjing J., Monica A., (2018). How Social Media Has Changed Us: The Good and TheBad. Retrieved November 2018, fromhttp://www.pewinternet.org/2018/05/31/teens-social-media-technology$2018 /$

Karasar, N. (2016). Bilimsel Araştırma Yöntemi. Ankara: Nobel Yayıncılık.

Kircaburun, K. \& Griffiths, M.D. (2018). Instagram addiction and the big five of personality: The mediating role of self-liking. Journal of Behavioral Addictions, in press. DOI: 10.1556/2006.7.2018.15

Kobiruzzaman M, M. (2018). Impact of Social Media Towards Society, A Case Study on Teenagers International Journal of Education and Knowledge Management (IJEKM) 1(3): 1-12 Print ISSN: 2616-51980nline ISSN: $2616-4698$

Koca, Eda Büyükgebiz, Mustafa Zihni Tunca (2019). İnternet Ve Sosyal Medya Bağımlılığının Öğrencilerin Performanslarına Etkileri Üzerine Bir Yazın Taraması Süleyman Demirel Üniversitesi İktisadi Ve İdari Bilimler Fakültesi Dergisi Y.2019, C.24, S.1, S.33-53. Y.2019, Vol.24, No.1, Pp.33-53. 33

Kraut, R., Kiesler, S., Mukhopadhyay, T., Scherlis, W., Patterson, M. (1998). Social impact of the internet: What does it mean? Communications of the ACM; 41(12): $21-22$.

Kubey, R., Czikszentmihalyi, M. (2002). Robert Kubey and Mihaly Czikszentmihalyi, Television addiction is no mere metaphor, Scientific American 286, (2), pp. 74-80

Kuss, D. J. \& Griffiths, M. D. (2011). Internet gaming addiction: A systematic review of empirical research. International Journal of Mental Health and Addiction, in press. doi: 10.1007/s11469-011-9318-5 
Müezzin, E. (2017). "Lise Öğrencilerinde İnternet Bağımlılığının Yoksunluk, Kontrol Güçlüğü, İşlevsellikte Bozulma Ve Sosyal İzolasyon Bağlamında İncelenmesi”, Sakarya University Journal Of Education, 7(3): 541-551.

Nakaya, A. C. (2015). Internet and social media addiction. San Diego, CA: ReferencePoint Press.

Okumuş, V. (2018). Çocukların sosyal medya kullanımları ile ebeveyn tutumları arasındaki ilişkinin incelenmesi. Yüksek Lisans Tezi. İstanbul Ticaret Üniversitesi, İstanbul.

Parents, (2018). Social media and teenagers, from https://parents.au.reachout.com/skills-to-build/wellbeing/social-media-andteenagers Washington, DC: Pew Internet \& American Life Project. (erişim tarihi: 23. 2.2021)

Rachel E. (2016). Experts say kids are growing up with more anxiety and less selfesteemRetrieved November 13, 2018, from https://childmind.org/article/howusing-social-media-affects-teenagers/

Sağar, M.E. (2018). Gençlerde Güncel Sorunlardan Biri Olan Sosyal Medya Bağımlılı̆̆ının İncelenmesi: Afyon İli Örneği. Alanya Uluslararası Yerel Yönetimler Sempozyumu. 01- 03.11.2018. Alanya, Türkiye.

Sağar, Mehmet Enes. (2019). Yetişkin Bireylerde Sosyal Medya Bağımlılığının İrdelenmesi Sağlık Bilimlerinde Eğitim Dergisi ISSN: $2687-4393$ SBED2019: 1(1)

Savcı, M. ve Aysan, F. (2017). Teknolojik Bağımlılıklar ve Sosyal Bağl11ı: İnternet Bağımlılı̆̆ı, Sosyal Medya Bağımlılığı, Dijital Oyun Bağımlılığı ve Akıllı Telefon Bağımlılığının Sosyal Bağllı̆̆ı Yordayıcı Etkisi. Düşünen Adam (30), 202-216.

Shaw, M., \& Black, D. W. (2008). Internet Addiction Definition, Assessment, Epidemiology and Clinical Management. CNS Drugs, 22, 353-365.

Solmaz, B, Tekin, G, Herzem, Z , Demir, M . (2013). İnternet Ve Sosyal Medya Kullanımı Üzerine Bir Uygulama. Selçuk İletişim, 7 (4) , 23-32 . Retrieved From https://dergipark.org.tr/tr/pub/josc/issue/19027/200546

Şahan, M. Ve Eraslan Çapan, B. (2017). "Ergenlerin Problemli İnternet Kullanımında Kişilerarası İlişkilerle İlgili Bilişsel Çarpıtmaların Ve Sosyal Kaygının Rolü’, Ege Eğitim Dergisi, 18(2): 887-913.

Turkish Academic Research Review - Türk Akademik Araştırmalar Dergisi https://dergipark.org.tr/tr/pub/tarr 
Taşçı, B. Ve Ekiz, S. (2018). "Serbest Zaman Aktivitesi Olarak Sosyal Medya Bağımlılı̆̆ı", 2. Uluslararası İletişimde Yeni Yönelimler Konferansı: Eğlence ve Ürün Yerleştirme, 224-235

TDK (2021). Bağımlı: https://sozluk.gov.tr/ (erişim tarihi 24.04.2021)

Tutgun-Ünal, A. \& Deniz, L. (2015). Development of the Social Media Addiction Scale. Online Academic Journal of Information Technology (AJIT-e), 6(21), 51-70.

Uslu, Mustafa (2020). Pandemi Sürecinde Sosyal Medya Bağımlılığı, Kitap: Dijitalleşme Eğilimleri- Covı-19 Pandemisi Sonrası Dijitalleşme Eğilimlerinin Sosyal Ve Beşeri Bilimlere Yansımaları (Ed. F. Uslu),Nobel Akademik Yayınc1lı, Ankara ISBN 978-625-7296-93-9

We are Social, Hootsuit (2020). Türkiye'de İnternet Kullanım ve Sosyal Medya İstatistikleri, Erişim adresi: https://dijilopedi.com/2020-turkiye-internetkullanim-ve-sosyal-medya-istatistikleri/ (erişim tarihi 20.04.2021)

Yang, S. C. \& Tung, C. J. (2007). Comparison of internet addicts and nonaddicts in Taiwanese high school. Comput Human Behavior, 23: 79-96.

Yang, C. C., \& Lee, Y. (2018). Interactants and activities on Facebook, Instagram, andTwitter: Associations between social media use and social adjustment tocollege. Applied Developmental Science, 1-17.

Yılmazsoy, B., Kahraman, M. (2017). Üniversite öğrencilerinin sosyal medya bağımlılığı ile sosyal medyayı eğitsel amaçlı kullanımları arasındaki ilişkinin incelenmesi: Facebook örneği. Journal of Instructional Technologies \& Teacher Education; 6(1): 9-20.

Young, K.S. (2007). "Cognitive Behavior Therapy with Internet Addicts: Treatment Outcomes and Implications", CyberPsychology and Behavior, 10(5), 671679.

Zorbaz, O, Dost, M. (2014). Lise Öğrencilerinin Problemli İnternet Kullanımının Cinsiyet, Sosyal Kaygı ve Akran İlişkileri Açısından İncelenmesi. Hacettepe Üniversitesi Eğitim Fakültesi Dergisi, 29 (29-1) , 298-310 . Retrieved from https://dergipark.org.tr/tr/pub/hunefd/issue/7787/101801 